\title{
Monitoring the occurrence of glyphosate-resistant sourgrass biotypes in the south region of Minas Gerais, Brazil ${ }^{1}$
}

\author{
Monitoramento da ocorrência de biótipos de capim-amargoso resistentes ao \\ herbicida glyphosate na região do Sul de Minas Gerais, Brasil
}

\author{
Acácio Gonçalves Netto ${ }^{2}$; Yago Dias Goveia ${ }^{3}$; Saul Jorge Pinto de Carvalho ${ }^{4}$
}

\begin{abstract}
This work was developed with the objective of monitoring the occurrence of glyphosate-resistant biotypes of sourgrass (D. insularis) in Machado, Alpinópolis, Serrania and Divisa Nova, in the south region of Minas Gerais, Brazil. In each area, seeds of at least 20 plants were collected in full physiological maturity stage. For operational reasons, the analysis of different biotypes was divided into two timings, the first held in the second half of 2013 and the second in the first half of 2014. Plants were treated in the 4-5 leaves stage / tillering (First timing) and preflowering (Second timing); with the following treatments $\left(\mathrm{D}=720 \mathrm{~g} \mathrm{ha}^{-1}\right.$ a.e.): 4D, $\mathrm{D}, 1 / 4 \mathrm{D}, 1 / 16 \mathrm{D}$, 1/64D and herbicide absence. The percentage of control was evaluated at 14 and 28 days after application (DAA) as well as the residual dry mass at 28 DAA. Twelve sourgrass biotypes were considered susceptible to glyphosate; glyphosate differential susceptibility was detected between sourgrass biotypes; different management measures must be adopted to reduce the pressure of selection and the worsening of the situation.
\end{abstract}

Keywords: Digitaria insularis; dose response; management; prevention; resistance

Resumo - Este trabalho foi desenvolvido com o objetivo de monitorar a ocorrência de biótipos de capim-amargoso (D. insularis) resistentes ao herbicida glyphosate em Machado, Alpinópolis, Serrania e Divisa Nova, na região de Sul de Minas Gerais, Brasil. Em cada área, foram coletadas sementes de, no mínimo, 20 plantas por biótipos, em estádio de plena maturidade fisiológica. Por questões operacionais, a análise dos diferentes biótipos foi dividida em duas fases, a primeira realizada no segundo semestre de 2013 e a segunda realizada no primeiro semestre de 2014. Foram realizadas pulverizações sobre plantas em estádio de 4-5 folhas / perfilhamento (Primeira Fase) e em pré-florescimento (Segunda Fase), com os seguintes tratamentos ( $\mathrm{D}=720 \mathrm{~g} \mathrm{ha}^{-1} \mathrm{e} . \mathrm{a}$.): 4D, $\mathrm{D}$, $1 / 4 \mathrm{D}, 1 / 16 \mathrm{D}, 1 / 64 \mathrm{D}$ e ausência de herbicidas. Foi avaliado o controle percentual aos 14 e 28 dias após aplicação (DAA), bem como a massa seca residual aos 28 DAA. Os doze biótipos de capimamargoso testados foram considerados suscetíveis ao herbicida glyphosate. Detectou-se suscetibilidade diferencial entre os biótipos. Assim sendo, medidas de manejo diferentes devem ser adotadas para evitar o agravamento da situação.

Palavras-chaves: Digitaria insularis; dose-resposta; manejo; prevenção; resistência

\footnotetext{
${ }^{1}$ Received for publication on 29/07/2015 and approved on 29/08/2015.

${ }^{2}$ Mestrando em Fitotecnia, Esalq/USP, Av. Pádua Dias, 11, Piracicaba, SP, acaciogn@agronomo.eng.br;

${ }^{3}$ Graduando em Agronomia, IFSULDEMINAS - Campus Machado, ygoveia@ hotmail.com;

4 Professor Doutor, IFSULDEMINAS - Campus Machado, Rod. Machado-Paraguaçu, Km 3, Machado, MG, sjpcarvalho@yahoo.com.br
} 


\section{Introduction}

Weeds are among biotic factors that may directly or indirectly interfere on crops' growth and yield, competing by essential resources, releasing allelophatic substances in the environment or hosting pests (Leite Júnior \& Mohan, 1990). Currently, the intensive use of herbicides for weed management is the most adopted practice in agriculture (Yang et al., 2007). Nowadays, glyphosate is the most important herbicide in the world, and it has been used for many years to control annual or perennial weeds, in many cropping systems (Faircloth et al., 2001; Blackshaw \& Harker, 2002).

Currently, one of the most important discussion about weed management in Brazilian or Global agricultural crops is the selection of herbicide-resistant weed biotypes. Herbicide weed resistance may be defined as the inherent and inheritable capacity of certain biotypes, among weed population, to survive and reproduce after being exposed to a herbicide dose which would be lethal to susceptible individuals of the same species (Christoffoleti \& López-Ovejero, 2008).

Resistance is a natural phenomenon that spontaneously occurs in weed populations; then, the herbicide does not cause resistance, it just works selecting resistant individuals that may be found naturally in the population, although with small initial frequency (López-Ovejero et al., 2006). This selection is related to the great genetic variability that is common on weed populations. This variability allows weed to adapt and survive in the most diverse environmental conditions (Christoffoleti \& López-Ovejero, 2003).

Weed management is also essential in coffee (Coffea spp.) plantations, since this crop is extremely sensible to weed competition by nutrients (Ronchi \& Silva, 2006), light and water, causing damages to flowering, fruiting and hence its yield (Alcântara \& Ferreira, 2000). In the south region of Minas Gerais State, Brazil, there are no confirmed cases of glyphosate-resistant weed species; however, frequently, weed management in coffee plantations is strongly based on several annual applications of this herbicide. This environment is extremely favorable for selecting herbicideresistant weed biotypes, which must be monitored carefully.

Sourgrass (Digitaria insularis) is a weed frequently found in Brazilian pastures, coffee plantations, orchards, roadsides and vacant lands. This weed used to be less common in cultivated soils, however currently it has been identified as one of the most important weed in no-tillage areas of the cerrado and in southern Brazil. It grows vigorously, forming clumps that bloom during almost all the summer (Lorenzi, 2008). The first world case of a glyphosateresistant sourgrass biotype was reported in Paraguay, in 2005 (Heap, 2015). In Brazil, the first cases were reported in 2008 and 2011 (Melo, 2011; Carvalho et al., 2011; Heap, 2015), in soybean and maize fields and in citrus orchards.

Considering sourgrass is easily found in coffee plantations frequently managed with glyphosate, the objective of this work was monitoring the occurrence of glyphosateresistant biotypes of sourgrass $(D$. insularis) in Machado, Alpinópolis, Serrania and Divisa Nova, in the south region of Minas Gerais, Brazil.

\section{Material and Methods}

This work was carried out in greenhouse condition at the Federal Institute of Education, Science and Technology of the South of Minas Gerais (MG), Machado campus, Brazil (21 $41^{\circ}$ S; $45^{\circ} 44^{\prime} \mathrm{W} ; 850 \mathrm{~m}$ of altitude).

Twelve independent trials were developed to evaluate glyphosate control of sourgrass (Digitaria insularis) biotypes. These biotypes were sampled on different growth environments (coffee plantations, glyphosate applying areas, urban area and fallow land), in the cities of Machado, Alpinópolis, Serrania and Divisa Nova (MG). In each area, seeds were 
collected in bulk from at least 20 plants, in representative infestations, in the stage of complete physiological maturity. At the harvest moment, geographical coordinates were noted for each sampling point (Table 1).

Table 1. Sampling points for biotypes of sourgrass (Digitaria insularis), cities, geographic coordinates and altitude.

\begin{tabular}{|c|c|c|c|c|c|}
\hline \multirow{2}{*}{ Biotypes } & \multirow{2}{*}{ Municipality } & \multirow{2}{*}{ Soil Use } & \multicolumn{2}{|c|}{ Geographic Coordinate } & \multirow{2}{*}{$\begin{array}{l}\text { Altitude } \\
\text { (m) }\end{array}$} \\
\hline & & & Latitude & Longitude & \\
\hline A & Machado & Coffee & $21^{\circ} 39^{\prime} 55^{\prime \prime}$ & $45^{\circ} 51^{\prime} 05^{\prime \prime}$ & 876 \\
\hline $\mathrm{B}$ & Machado & Coffee & $21^{\circ} 43^{\prime} 05^{\prime \prime}$ & $45^{\circ} 53^{\prime} 32^{\prime \prime}$ & 909 \\
\hline $\mathrm{C}$ & Machado & Corn / Fallow & $21^{\circ} 40^{\prime} 15^{\prime \prime}$ & $45^{\circ} 55^{\prime} 03^{\prime \prime}$ & 849 \\
\hline $\mathrm{D}$ & Machado & Coffee & $21^{\circ} 36^{\prime} 56^{\prime \prime}$ & $45^{\circ} 57^{\prime} 15^{\prime \prime}$ & 970 \\
\hline $\mathrm{E}$ & Machado & Cucumber & $21^{\circ} 43^{\prime} 01^{\prime \prime}$ & $45^{\circ} 57^{\prime} 07^{\prime \prime}$ & 853 \\
\hline $\mathrm{F}$ & Machado & Urban Area & $21^{\circ} 40^{\prime} 53^{\prime \prime}$ & $45^{\circ} 55^{\prime} 49^{\prime \prime}$ & 859 \\
\hline $\mathrm{G}$ & Alpinópolis & Soybean & $20^{\circ} 47^{\prime} 58^{\prime \prime}$ & $46^{\circ} 21^{\prime} 39^{\prime \prime}$ & 790 \\
\hline $\mathrm{H}$ & Serrania & Coffee & $21^{\circ} 34^{\prime} 31^{\prime \prime}$ & $46^{\circ} 08^{\prime} 50^{\prime \prime}$ & 955 \\
\hline $\mathrm{I}$ & Divisa Nova & Sunflower & $21^{\circ} 33^{\prime} 20^{\prime \prime}$ & $46^{\circ} 10^{\prime} 54^{\prime \prime}$ & 825 \\
\hline $\mathrm{J}$ & Serrania & Coffee & $21^{\circ} 29^{\prime} 28^{\prime \prime}$ & $46^{\circ} 03^{\prime} 03^{\prime \prime}$ & 870 \\
\hline $\mathrm{K}$ & Serrania & Coffee & $21^{\circ} 29^{\prime} 36^{\prime \prime}$ & $46^{\circ} 02^{\prime} 59^{\prime \prime}$ & 882 \\
\hline
\end{tabular}

Seeds of each biotype were homogenized and stored in paper bags, in a dry place at room temperature, until the beginning of the trials. For growing the seedlings, seeds were distributed on $4 \mathrm{~L}$ commercial plastic pots, filled with a mix of commercial substrate (Pinus bark, turf and vermiculite) and vermiculite (3:1 $\mathrm{v} / \mathrm{v})$. At two unfolded leaves stage, seedlings were transplanted to experimental plots, where they remained up to the end of the trials. Experimental plots consisted of 1L plastic pots, filled with the same mixture of substrate and vermiculite, properly fertilized. Plots had the mean of ten plants, without nutritional or water stress.

For operational reasons, the analysis of several biotypes was divided into two phases. First, half of the biotypes were evaluated in the second half of 2013. After that, the other half of the biotypes were studied in the first half of 2014. Biotypes susceptibility to glyphosate was quantified through the method of dose-response curves. Each biotype was considered as an independent trial installed on a randomized blocks experimental design, with six treatments (glyphosate doses) and five replicates, totaling
30 plots. In this case, small variability in size or number of plants per pot was considered the factor for blocking the trials. On each biotype, it was applied the same six glyphosate (Roundup Original ${ }^{\circledR}$ ) doses, as follows: 4D, D, 1/4D, $1 / 16 \mathrm{D}, 1 / 64 \mathrm{D}$ and herbicide absence. The $\mathrm{D}$ is the herbicide recommended dose, proportional to $720 \mathrm{~g} \mathrm{ha}^{-1}$ of glyphosate acid equivalent (a.e.). Doses were chosen considering susceptible biotypes, since using higher doses could not allow the comparisons, if all the doses might promote $100 \%$ of control.

In the first phase, glyphosate was applied on plants at the 4-5 leaves / full tillering stage (biotypes A to $\mathrm{G}$ ); in the second phase, plants were applied on pre-flowering stage (biotypes $\mathrm{H}$ to $\mathrm{K}+\mathrm{F}$ ) at the application timing. Herbicide treatments were applied using a $\mathrm{CO}_{2}$-backpack sprayer, coupled to a two nozzles bar (flat fan TeeJet XR 110.02), positioned at $0.50 \mathrm{~m}$ above the targets and with consumption of spray solution proportional to $200 \mathrm{~L} \mathrm{ha}^{-1}$. After herbicide application, pots were placed in the greenhouse and irrigated on the following day to secure adequate foliar absorption of the 
molecules. Meteorological data were locally collected at the time of applications (Table 2).

Sourgrass control was evaluated at 14 and 28 days after application (DAA), as well as the residual dry mass was measured at 28 DAA. For control evaluations, it was considered a percentage scale variable from zero up to $100 \%$, in which zero means the absence of symptoms and 100 means plant death. Dry mass values were obtained from the harvest of all remaining plant material in the plots, with subsequent drying in an oven at $70{ }^{\circ} \mathrm{C}$ for $72 \mathrm{~h}$. These values were corrected to percentage by comparing the residual mass of each herbicide treatment with the mass of control plots (herbicide absence), considered as $100 \%$.

Table 2. Description of days and meteorological conditions of herbicide application on sourgrass (Digitaria insularis) biotypes. Machado (MG), 2013/14.

\begin{tabular}{lccc}
\hline \multirow{2}{*}{ Application } & \multicolumn{3}{c}{ Application } \\
\cline { 2 - 4 } & $10 / 09 / 2013$ & $10 / 24 / 2013$ & $03 / 24 / 2014$ \\
\hline Biotype & $\mathrm{A}, \mathrm{B}, \mathrm{C}, \mathrm{D}, \mathrm{E}, \mathrm{F}$ & $\mathrm{G}$ & $\mathrm{H}, \mathrm{I}, \mathrm{J}, \mathrm{K}, \mathrm{F}$ \\
Start time & $15: 55 \mathrm{~h}$ & $09: 01 \mathrm{~h}$ & $15: 35 \mathrm{~h}$ \\
End time & $16: 02 \mathrm{~h}$ & $09: 13 \mathrm{~h}$ & $15: 50 \mathrm{~h}$ \\
Mean Temperature $\left({ }^{\circ} \mathrm{C}\right)$ & 25.6 & 25.3 & 29.8 \\
Relative Humidity $(\%)$ & 54.1 & 73.7 & 50.3 \\
Wind $(\mathrm{m} / \mathrm{s})$ & 0.1 & 0.0 & 0.2 \\
Atmosphere condition & Partly covered $(80 \%)$ & Clean & Covered \\
\hline
\end{tabular}

Initially, data analysis was performed by applying the $\mathrm{F}$ test on analysis of variance. Considering that the maximum dose has reached $100 \%$ of control, dose-response curves were fitted according to non-linear log-logistic model with two parameters, adapted by Carvalho et al. (2010):

$$
y=\frac{100}{\left[1+\left(\frac{x}{L D_{50}}\right)^{\alpha}\right]}
$$

In which: $y$ is the variable (control or percentage of dry mass), $x$ is the herbicide dose ( $\mathrm{g} \mathrm{ha}^{-1}$ a.e.), $L D_{50}$ is the herbicide lethal dose that reduces $50 \%$ of variable response $(50 \%$ of control or reduction of mass) and $\alpha$ is the slope of the curve around $L D_{50}$.

The log-logistic model presents advantages once one of the equation parameter is an estimative of $L D_{50} . L D_{50}$ (lethal dose to $50 \%)$ is the herbicide dose $\left(\mathrm{g} \mathrm{ha}^{-1}\right.$ a.e. $)$ that promotes $50 \%$ of control or weeds' weight reduction (Carvalho et al., 2009). Considering agronomic efficacy, it was also calculated $L D_{80}$, i.e., the herbicide dose necessary to control the biotype up to $80 \%$ or to reduce $80 \%$ of dry mass.

\section{Results and Discussion}

Log-logistic models were fit to the data, with coefficients of determination always above 0.90 (Tables 3 and 4). Considering control evaluation at $14 \mathrm{DAA}, L D_{50}$ values were below $720 \mathrm{~g} \mathrm{ha}^{-1}$ a.e. for all biotypes, what is equivalent to $2 \mathrm{~L} \mathrm{ha}^{-1}$ of commercial product (Roundup Original ${ }^{\circledR} ; 360 \mathrm{~g} \mathrm{~L}^{-1}$ a.e.). In this evaluation, it was also possible to observe that plants on pre-flowering stage (second phase) were more difficult to control with glyphosate than plants on tillering stage (first phase), mainly if $L D_{80}$ is considered. In both phases, biotype $\mathrm{F}$ was the most difficult to control, demanding doses up to $2,650 \mathrm{~g} \mathrm{ha}^{-1}$ a.e. for $L D_{80}$, that is highly above commercial recommendation (Rodrigues \& Almeida, 2011) (Table 3).

Curiously, biotype $\mathrm{F}$ was sampled in Machado urban area. Once herbicide application in urban area is legally forbidden, 
and considering the possibilities of sourgrass dispersal, it is possible that this biotype may be exposed to glyphosate elsewhere and then transported to urban areas.

Table 3. Parameters ${ }^{1}$ of the equation for sourgrass (Digitaria insularis) control after the application of six glyphosate doses, evaluated at 14 and 28 DAA. Machado (MG), 2013/14.

\begin{tabular}{|c|c|c|c|c|}
\hline \multicolumn{5}{|c|}{$\%$ of control - 14 DAA } \\
\hline \multirow{3}{*}{ Biotype } & \multicolumn{4}{|c|}{ Statistical Parameter } \\
\hline & $L D_{50}$ & $\alpha$ & $L D_{80}$ & $\mathrm{R}^{2}$ \\
\hline & \multicolumn{4}{|c|}{ Plants with 4 to 5 leaves/Tillering } \\
\hline A & 250.462 & -1.801 & 540.797 & 0.997 \\
\hline $\mathrm{B}$ & 263.281 & -1.922 & 541.584 & 0.997 \\
\hline $\mathrm{C}$ & 245.943 & -1.799 & 531.494 & 0.996 \\
\hline $\mathrm{D}$ & 246.125 & -1.561 & 598.197 & 0.996 \\
\hline $\mathrm{E}$ & 215.829 & -1.628 & 505.738 & 0.998 \\
\hline $\mathrm{F}$ & 332.578 & -1.204 & 1051.825 & 0.998 \\
\hline \multirow[t]{2}{*}{$\mathrm{G}$} & 356.928 & -1.524 & 886.407 & 0.997 \\
\hline & \multicolumn{4}{|c|}{ Plants on pre-flowering } \\
\hline $\mathrm{H}$ & 283.286 & -1.059 & 1048.921 & 0.998 \\
\hline $\mathrm{I}$ & 379.500 & -1.043 & 1433.674 & 0.994 \\
\hline $\mathrm{J}$ & 354.417 & -1.136 & 1200.873 & 0.998 \\
\hline $\mathrm{K}$ & 317.108 & -1.109 & 1106.860 & 0.998 \\
\hline $\mathrm{F}$ & 516.059 & -0.847 & 2651.636 & 0.991 \\
\hline \multicolumn{5}{|c|}{$\%$ of control -28 DAA } \\
\hline \multirow{3}{*}{ Biotype } & \multicolumn{4}{|c|}{ Statistical Parameter } \\
\hline & $L D_{50}$ & $\alpha$ & $L D_{80}$ & $\mathrm{R}^{2}$ \\
\hline & \multicolumn{4}{|c|}{ Plants with 4 to 5 leaves/Tillering } \\
\hline A & 227.460 & -3.340 & 344.479 & 0.996 \\
\hline $\mathrm{B}$ & 224.589 & -2.851 & 365.228 & 0.994 \\
\hline $\mathrm{C}$ & 196.039 & -1.970 & 396.239 & 0.993 \\
\hline $\mathrm{D}$ & 236.279 & -4.644 & 318.469 & 0.997 \\
\hline $\mathrm{E}$ & 207.706 & -3.363 & 313.671 & 0.999 \\
\hline $\mathrm{F}$ & 207.007 & -3.120 & 322.814 & 0.999 \\
\hline \multirow[t]{2}{*}{$\mathrm{G}$} & 239.123 & -3.311 & 363.461 & 0.999 \\
\hline & \multicolumn{4}{|c|}{ Plants on pre-flowering } \\
\hline $\mathrm{H}$ & 158.563 & -1.423 & 420.043 & 0.994 \\
\hline $\mathrm{I}$ & 236.914 & -1.239 & 725.295 & 0.997 \\
\hline $\mathrm{J}$ & 198.804 & -1.703 & 448.698 & 0.998 \\
\hline $\mathrm{K}$ & 161.079 & -1.547 & 394.655 & 0.997 \\
\hline $\mathrm{F}$ & 241.089 & -1.482 & 614.364 & 0.999 \\
\hline
\end{tabular}

${ }^{1}$ Mathematical model: $y=100 /\left(1+\left(x / \mathrm{R}_{50}\right)^{\alpha}\right)$; LD $\mathrm{LD}_{50}=$ dose of glyphosate that controls $50 \%$ of weed; $\alpha=$ slope of the curve; $\mathrm{R}^{2}=$ coefficient of determination; $\mathrm{LD}_{80}=$ dose of glyphosate that controls $80 \%$ of weed.

At 28 DAA, $360 \mathrm{~g} \mathrm{ha}^{-1}$ a.e. of glyphosate were enough to ensure $L D_{50}$ of all biotypes. Considering $L D_{80}$, biotype $I$ was the most difficult to control, demanding $725 \mathrm{~g} \mathrm{ha}^{-1}$ a.e. of glyphosate (Table 3). In this second evaluation, $L D_{50}$ and $L D_{80}$ values were lower than at 14 DAA, that may be explained by the time necessary for glyphosate killing the weeds, 
about 14 to 21 days. Considering dry mass evaluation at 28 DAA, $L D_{80}$ could be reached with the glyphosate commercial dose, up to $1,440 \mathrm{~g} \mathrm{ha}^{-1}$ a.e., what indicates these biotypes are not resistant to the product, however they have differential levels of susceptibility (Table 4).

Table 4. Parameters ${ }^{1}$ of the equation for sourgrass (Digitaria insularis) dry mass after the application of six glyphosate doses, evaluated at 28 DAA. Machado - MG, 2013/14

\begin{tabular}{ccccc}
\hline \multirow{2}{*}{ Biotype } & $L D_{50}$ & \multicolumn{4}{c}{ Statistical Parameter } \\
\cline { 2 - 4 } & \multicolumn{4}{c}{ Plants with 4 to 5 leaves/Tillering } \\
\cline { 2 - 4 } & 301.503 & 2.453 & 530.554 & $\mathrm{R}^{\mathbf{2}}$ \\
\hline A & 124.585 & 1.140 & 420.328 & 0.986 \\
B & 117.878 & 1.032 & 451.673 & 0.991 \\
C & 233.008 & 1.320 & 666.004 & 0.993 \\
D & 173.739 & 1.883 & 362.770 & 0.991 \\
E & 183.838 & 1.782 & 400.213 & 0.929 \\
F & 193.501 & 3.002 & 307.069 & 0.996 \\
G & \multicolumn{4}{c}{ Plants on pre-flowering } \\
\hline H & 140.581 & 1.034 & 537.266 & 0.983 \\
I & 151.965 & 0.787 & 884.606 & 0.988 \\
J & 242.544 & 0.923 & 1089.122 & 0.983 \\
K & 130.798 & 0.819 & 710.750 & 0.984 \\
F & 239.942 & 0.816 & 1311.973 & 0.995 \\
\hline
\end{tabular}

${ }^{1}$ Mathematical model: $y=100 /\left(1+\left(x / \mathrm{R}_{50}\right)^{\alpha}\right)$; $\mathrm{LD}_{50}=$ dose of glyphosate that controls $50 \%$ of weed; $\alpha=$ slope of the curve; $\mathrm{R}^{2}=$ coefficient of determination; $\mathrm{LD}_{80}=$ dose of glyphosate that controls $80 \%$ of weed.

Frequently, control of sourgrass adult plants demands the application of glyphosate doses superior than those recommended to control other species of the Poaceae family. Timossi et al. (2006) observed that $1,440 \mathrm{~g} \mathrm{ha}^{-1}$ a.e. of glyphosate were necessary to promote satisfactory control of the infesting population, but it did not prevent its regrowth. In field condition, in areas with glyphosate continuous use, young plants originated from seeds have been adequately controlled by the herbicide; however, when they develop and create rhizomes, its control is inefficient (Machado et al., 2006).

Machado et al. (2008) commented that the higher difficult to control sourgrass plants emerged from rhizomes may be related to the increased thickness of adaxial and abaxial epidermis as well as to the increased thickness of the leaf blade, when compared to plants grown from seeds. They also observed great amount of starch in the rhizomes, that may difficult glyphosate translocation and allow fast shoot regrowth. Therefore, not always a hard-tokill biotype is a resistant biotype. Low susceptibility may also be related to advanced phenological stage, plant physiology and morphology.

Considering control at 14 and 28 DAA and dry mass, it was evident that plants phenological stage at the application moment is a very important detail to be observed for reaching complete control with glyphosate. Always, applying glyphosate on pre-flowering plants demanded higher doses than applying glyphosate on tillering plants (Tables 3 and 4). For example, considering dry mass of biotype F, dose necessary to control plants on preflowering was three times higher than the 
necessary dose to control the same biotype on tillering stage (Table 4).

The influence of phenological stage on glyphosate efficacy has been greatly reported in literature. For example, $15.8 \mathrm{~g} \mathrm{ha}^{-1}$ a.e. of glyphosate were enough to reach $L D_{50}$ of Commelina benghalensis on cotyledon leaves stage. However, more than 2,880 $\mathrm{g} \mathrm{ha}^{-1}$ a.e. of glyphosate were necessary to reach $L D_{50}$ of the same population, when considering preflowering plants. In the same work, glyphosate dose necessary to control pre-flowering Brachiaria plantaginea was five times fold than application on cotyledon leaves plants (Dias et al., 2013).

Christoffoleti et al. (2005) and Ribeiro (2008) also reported the interference of plants phenological stage on glyphosate efficacy. These authors evaluated resistant biotypes of Lolium multiflorum and observed lower levels of control on the most developed plants. Lacerda \& Victoria Filho (2004) also evaluated glyphosate control of $D$. insularis. These authors observed that only $128.5 \mathrm{~g} \mathrm{ha}^{-1}$ a.e. of glyphosate was enough to reach $R_{50}$ of young plants on the stage of four unfolded leaves.

Nicolai et al. (2010) carried out experiments with sourgrass biotypes collected in the region of Matão, São Paulo State, Brazil. These authors reported the necessity of glyphosate doses between 4,320 and 5,760 $\mathrm{g}^{-} \mathrm{a}^{-}$ ${ }^{1}$ a.e. to control some biotypes, with resistance factor of 7,5 (R/S). Adegas et al. (2010) carried out another similar work, in the municipality of Guaíra, Paraná State, Brazil. These authors found out biotypes which $8,640 \mathrm{~g} \mathrm{ha}^{-1}$ a.e. of glyphosate resulted on only $77 \%$ of control, with factor $\mathrm{R} / \mathrm{S}$ of 6,4 . The $\mathrm{R} / \mathrm{S}$ factor corresponds to the division of $L D_{50}, L D_{80}$ or $L D_{95}$ of the unknown susceptibility biotype by the susceptible biotype (Christoffoleti \& LópezOvejero, 2008).

Correia et al. (2010) also reported glyphosate differential susceptibility of sourgrass populations, what enunciated the selection of glyphosate-resistant biotypes. In this work, doses up to $3,988 \mathrm{~g} \mathrm{ha}^{-1}$ a.e. were necessary to reach $L D_{50}$, at $28 \mathrm{DAA}$. Although it has been commercialized since 70s, the first world case of a glyphosate-resistant weed was only reported in 1996 (Pratley et al., 1996). This several years delay may be explained mainly due to biochemical characteristics of the molecule when it is in the plants or soil, such as: absence of soil residual activity, presence of multiple physiological paths related to the action mechanism, low ecological adaptability of surviving individuals, low initial frequency of resistant individuals, absence of other herbicides with the same action mechanism and limited metabolism in the plants (Bradshaw et al., 1997).

In addition, in the last few years, higher number of glyphosate applications have been observed in agricultural areas as consequence of soil management conservationist systems (notillage) as well as the possibility of glyphosate application on transgenic crops. The higher number of annual glyphosate applications has increased significantly the risk of new cases of glyphosate-resistant biotypes, due to the pressure of selection created by the herbicide (Neve et al., 2003). In this way, since 2008 and 2011, new cases of glyphosate-resistant biotypes of sourgrass have been published in Brazil (Melo, 2011; Carvalho et al., 2011; Heap, 2015).

Monitoring glyphosate susceptibility of sourgrass biotypes is very important, mainly in coffee plantations of the south of Minas Gerais State. In general, differential susceptibility of sourgrass biotypes was identified in samples collected in the cities of Machado, Alpinópolis, Serrania and Divisa Nova, Minas Gerais State. Level of control obtained up to this moment do not characterize cases of resistance, however new management programs may be structured considering these data, including different herbicides or management practices, in order to prevent or avoid cases of sourgrass glyphosate resistance in the areas. 


\section{Conclusions}

All sourgrass biotypes were considered susceptible to glyphosate.

Glyphosate differential susceptibility was detected between sourgrass biotypes.

The different management measures must be adopted to reduce the pressure of selection and the worsening of the situation.

\section{Acknowledgements}

The authors wish to thank Brazilian National Council for Scientific and Technological Development $\mathrm{CNPq}$ for the support to this research, especially for the scientific initiation scholarship granted to the first author.

\section{References}

Adegas, F.S.; Gazziero, D.L.P.; Voll, E.; Osipe, R. Diagnóstico da existência de Digitaria insularis resistente ao herbicida glyphosate no sul do Brasil. In.: CONGRESSO BRASILEIRO DA CIÊNCIA DAS PLANTAS DANINHAS, 27., Ribeirão Preto, 2010. Anais... SBCPD: Ribeirão Preto, 2010. p.761-765.

Alcântara, E.N.; Ferreira, M.M. Efeito de diferentes métodos de controle de plantas daninhas sobre a produção de cafeeiros (Coffea arabica L.) instalados em Latossolo Roxo distrófico. Ciência Agrotécnica, v.24, n.1, p.54-61, 2000.

Blackshaw, R.E.; Harker, K.N. Selective weed control with glyphosate in glyphosate-resistant spring wheat (Triticum aestivum). Weed Technology, v.16, n.4, p.885-892, 2002.

Bradshaw, L.D.; Padgette, S.R.; Kimball, S.L.; Wells, B.H. Perspectives on glyphosate resistance. Weed Technology, v.11, n.1, p.189198, 1997.

Carvalho, L.B.; Cruz-Hipolito, H.; GonzálezTorralva, F.; Alves, P.L.C.A.; Christoffoleti, P.J.; Prado, R. Detection of sourgrass (Digitaria insularis) biotypes resistant to glyphosate in
Brazil. Weed Science, v.59, n.2, p.171-176, 2011.

Carvalho, S.J.P.; Christoffoleti, P.J.; LópezOvejero, R.F. Métodos para comprovação da resistência de plantas daninhas a herbicidas. In: Agostinetto, D.; Vargas, L. (Org.). Resistência de plantas daninhas a herbicidas no Brasil. Passo Fundo: Berthier, 2009. p. 103-122.

Carvalho, S.J.P.; Dias, A.C.R.; Shiomi, G.M.; Christoffoleti, P.J. Adição simultânea de sulfato de amônio e ureia à calda de pulverização do herbicida glyphosate. Planta Daninha, v.28, n.3, p.575-584, 2010.

Christoffoleti, P.J.; López-Ovejero, R. Principais aspectos da resistência de plantas daninhas ao herbicida glyphosate. Planta Daninha, v.21, n.3, p.507-515, 2003.

Christoffoleti, P.J.; López-Ovejero, R.F. Resistência das plantas daninhas a herbicidas: definições, bases e situação no Brasil e no mundo. In: Christoffoleti, P. J. (Coord.). Aspectos de resistência de plantas daninhas a herbicidas. 3.ed. Piracicaba: HRAC-BR, 2008. p. 3-30.

Christoffoleti, P.J.; Trentin, R.; Tocchetto, S.; Marochi, A.; Galli, A.J.; López-Ovejero, R.F.; Nicolai, M. Alternative herbicides to manage Italian ryegrass (Lolium multiflorum Lam.) resistant to glyphosate at different phenological stages. Journal of Environmental Science and Health, Part B, v.40, n.1, p.59-67, 2005.

Correia, N.M.; Leite, G.J.; Garcia, L.D. Resposta de diferentes populações de Digitaria insularis ao herbicida glyphosate. Planta Daninha, v.28, n.4, p.769-776, 2010.

Dias, A.C.R.; Carvalho, S.J.P.; Christoffoleti, P.J. Fenologia da trapoeraba como indicador para tolerância ao herbicida glyphosate. Planta Daninha, v.31, n.1, p.185-191, 2013.

Faircloth, W.H.; Patterson, M.G.; Monks, C.D.; Goodman, W.R. Weed management programs for glyphosate-tolerant cotton (Gossypium 
hirsutum). Weed Technology, v.15, n.3, p.544551, 2001.

Heap, I. The international survey of herbicide resistant weeds. Disponível em: <http://www.weedscience.org/Summary/Speci es.aspx?WeedID=239>. Acesso em: 24 Ago. 2015.

Lacerda, A.L.S.; Victória Filho, R. Curvas doseresposta em espécies de plantas daninhas com uso do herbicida glyphosate. Bragantia, v.63, n.1, p.73-79, 2004.

Leite Júnior, R.P.; Mohan, S.K. Integrated management of citrus bacterial canker disease caused by Xanthomonas campestris pv. citri in the State of Paraná, Brazil. Crop Protection, v.9, n.1, p.3-7, 1990.

López-Ovejero, R.F.; Carvalho S.J.P.; Nicolai, M.; Christoffoleti, P.J. Suscetibilidade comparativa a herbicidas pós-emergentes de biótipos de Digitaria ciliaris resistente e suscetível aos inibidores da ACCase. Planta Daninha, v.24, n.4, p.789-796, 2006.

Lorenzi, H. Plantas daninhas do Brasil: terrestres, aquáticas, parasitas e tóxicas. Nova Odessa: Instituto Plantarum, 2008. 640p.

Machado, A.F.L.; Ferreira, L.R.; Ferreira, F.A.; Fialho, C.M.T.; Tuffi Santos, L.D.; Machado, M.S. Análise de crescimento de Digitaria insularis. Planta Daninha, v.24, n.4, p.641647, 2006.

Machado, A.F.L.; Meira, R.M.S.; Ferreira, L.R.; Ferreira, F.A.; Tuffi Santos, L.D.; Fialho, C.M.T.; Machado, M.S. Caracterização anatômica de folha, colmo e rizoma de Digitaria insularis. Planta Daninha, v.26, n.1, p.1-8, 2008.

Melo, M.S.C. Alternativas de controle, acúmulo de chiquimato e curva de crescimento de capimamargoso (Digitaria insularis) suscetível e resistente ao glyphosate. Dissertação (Mestrado), Escola Superior de Agricultura "Luiz de Queiroz", 2011. Piracicaba: ESALQ, 2011.73p.
Neve, P.; Diggle, A.J.; Smith, F.P.; Powles, S.B. Simulating evolution of glyphosate resistance in Lolium rigidum. II. Past, present and future of glyphosate use in Australian cropping. Weed Research, v.43, n.6, p.418-427, 2003.

Nicolai, M.; Melo, M.S.C.; López-Ovejero, R.F.; Christoffoleti, P.J. Monitoramento de infestações de populações de capim-amargoso (Digitaria insularis) suspeitas de resistência ao glifosato. In.: CONGRESSO BRASILEIRO DA CIÊNCIA DAS PLANTAS DANINHAS, 27., Ribeirão Preto, 2010. Anais... SBCPD: Ribeirão Preto, 2010. p.943-946.

Pratley, J.; Baines, P.; Eberbach, P.; Incerti, M.; Broster, J. Glyphosate resistance in annual ryegrass. In: ANNUALCONFERENCE OF THE GRASSLAND SOCIETY OF NEW SOUTHWALES, 11 . Proceedings... WaggaWagga: The Grassland Society of New South Wales, 1996. p.126.

Ribeiro, D.N. Caracterização da resistência ao herbicida glyphosate em biótipos da planta daninha Lolium multiflorum (Lam.). 2008. 102 f. Dissertação (Mestrado em Fitotecnia) - Escola Superior de Agricultura "Luiz de Queiroz", Universidade de São Paulo, Piracicaba, 2008.

Rodrigues, B.N.; Almeida, F.S. Guia de herbicidas. 6.ed. Londrina: Grarfmake, 2011. $697 \mathrm{p}$.

Ronchi, C.P.; Silva, A.A. Effects of weed species competition on the growth of young coffee plants. Planta Daninha, v.24, n.3, p.415423, 2006.

Timossi, P.C.; Durigan, J.C.; Leite, G.J. Eficácia de glyphosate em plantas de cobertura. Planta Daninha, v.24, n.3, p.475-480, 2006.

Yang, Y.; Wang, H.; Tang, J.; Chen, X. Effects of weed management practices on orchard soil biological and fertility properties in southeastern China. Soil Tillage Research, v.93, n.1, p.179-185, 2007. 